\title{
Thermal decomposition of natural dolomite
}

\author{
S GUNASEKARAN ${ }^{\dagger}$ and G ANBALAGAN* \\ PG and Research Department of Physics, Presidency College, Chennai 600 005, India \\ ${ }^{\dagger} \mathrm{PG}$ and Research Department of Physics, Pachaiyappa's College, Chennai 600 030, India
}

MS received 3 November 2006; revised 22 May 2007

\begin{abstract}
Thermal decomposition behaviour of dolomite sample has been studied by thermogravimetric (TG) measurements. Differential thermal analysis (DTA) curve of dolomite shows two peaks at $777 \cdot 8^{\circ} \mathrm{C}$ and $834^{\circ} \mathrm{C}$. The two endothermic peaks observed in dolomite are essentially due to decarbonation of dolomite and calcite, respectively. The TG data of the decomposition steps have also been analysed using various differential, difference-differential and integral methods, viz. Freeman-Carroll, Horowitz-Metzger, Coats-Redfern methods. Values of activation entropy, Arrhenius factor, and order of reaction have been approximated and compared. Measured activation energies vary between 97 and $147 \mathrm{~kJ} \mathrm{~mol}^{-1}$. The large fluctuation in activation energy is attributed to the presence of impurities such as $\mathrm{SiO}_{2}, \mathrm{Al}_{2} \mathrm{O}_{3}, \mathrm{Fe}_{2} \mathrm{O}_{3}, \mathrm{Cl}^{-}$etc in the samples. FTIR and XRD analyses confirm the decomposition reaction. SEM observation of the heat-treated samples at $950^{\circ} \mathrm{C}$ shows cluster of grains, indicating the structural transformation.
\end{abstract}

Keywords. TGA-DTA; FTIR; X-ray diffraction; dolomite.

\section{Introduction}

Dolomite typically occurs as the major constituent of sedimentary formations in association with calcite. Thermal analysis might offer the means of defining the fraction of each mineral lattice in such mixtures and the concentration of each cation in each lattice. The correlation of the thermal data with the structural pattern should provide a broader understanding of these minerals in their natural occurrence. Romero Salvador et al (1989) studied the effects of experimental variables i.e. sample weight, particle size, purge gas velocity and crystalline structure, on the kinetic parameters of calcium carbonate decomposition. Criado and Ortega (1992) studied the influence of particle size on the thermal decomposition of calcium carbonate and found that the activation energy of thermal decomposition of calcium carbonate smoothly increases as the particle size increases. This behaviour can be attributed to the lower particle size and greater fraction of $\mathrm{CaCO}_{3}$ molecules located on surface with regard to the bulk. Therefore, the activation energy decreases because of the extra calcium carbonate stored on the surface of the smaller particles. In general, it has been reported that a diminition of the activation energy takes place when the sample size increases. This behaviour would be attributed to the influence of heat and mass transfer effects because of the poor control that is usually exerted on both decomposition rate (i.e. rate of heat evolution) and pressure of

*Author for correspondence (anbu24663@yahoo.co.in) the environment. Many researchers have studied the kinetics of thermal decomposition of carbonate minerals (Powell and Searcy 1980; Warne et al 1981; Iwafuchi et al 1983; Borgwardt 1985; Yariv 1989; McInosh et al 1990; Rubiera et al 1991; McCauley and Johnson 1991; Mulokozi and Lugwisha 1992; Ersoy-Merichoyu et al 1993; Shoval et al 1993; Xiao et al 1997). A general review of the literature on the decomposition of carbonates indicates that a great deal of variability exists in the reported values of the decomposition temperatures, activation energies and rates of decomposition. Although the decomposition of NBS dolomite sample has been reported (Criado and Ortega 1991), there have been no systematic studies on dolomite samples having a small concentration of naturally occurring alkali earth salts. In this paper, the effect of chlorine ions on the decomposition kinetics of dolomite at various temperatures studied by differential thermal analysis, thermogravimetric analysis, Fourier transform infrared spectroscopy and powder X-ray diffraction, have been reported.

\section{Experimental}

Natural dolomite sample collected from Neralakere mines, Bagalkot area of (latitude, $16^{\circ} 11^{\prime}$, longitude, $75^{\circ} 45^{\prime}$ ) Karnataka state was ground with agate mortar and pestle. The powder sample with size, $1.2 \mathrm{~nm}$, was subjected to X-ray diffraction (XRD), Fourier-transform infrared spectroscopy (FT-IR) and thermal analyses (differential thermal analysis (DTA) and thermogravimetric analysis (TGA)). 
The particle size was determined using the Scherrer formula (Kunel et al 1997).

XRD analysis was performed with a SEIFERT X-ray diffractometer with $\mathrm{CuK} \alpha$ radiation $(\lambda=1.54 \AA), \mathrm{Cu}$ filter on secondary optics, $45 \mathrm{kV}$ power and $20 \mathrm{~mA}$ current. The powder sample was mounted on a quartz support to minimize background.

Perkin-Elmer spectrum one FT-IR spectrometer was used, and the samples were analysed in $\mathrm{KBr}$ pellets. Spectra were traced in the range $4000-400 \mathrm{~cm}^{-1}$, and the band intensities were expressed in transmittance (\%). The infrared analysis helped in the identification of the main groups in the carbonate samples.

The powder sample was heated in a muffle furnace under air atmosphere for $6 \mathrm{~h}$ in each temperature. The spectral recordings were carried out at room temperature.

Thermal analysis was performed in a simultaneous TG-DTA (Netzsch STA 409). The experimental conditions were: (i) continuous heating from room temperature to $1000^{\circ} \mathrm{C}$ at a heating rate of $10 \mathrm{~K} / \mathrm{min}$, (ii) $\mathrm{N}_{2}$-gas dynamic atmosphere $\left(90 \mathrm{~cm}^{3} \mathrm{~min}^{-1}\right)$, (iii) alumina, as reference material and (iv) sample: $53.37 \mathrm{mg}$ of the sample having grain size $1.2 \mathrm{~nm}$ without pressing. The temperature was detected with a Pt-Pt $13 \% \mathrm{Rh}$ thermocouple fixed in a position near the sample pan. TG and DTA curves were obtained. The following data was obtained by thermal analysis: (i) reaction peak temperature and main effect (endothermic or exothermic) and (ii) content of bound water, which is the weight loss in the temperature range $200-600^{\circ} \mathrm{C}$ and content of $\mathrm{CO}_{2}$ released during the decomposition of carbonate phases.

\section{Results and discussion}

Table 1 gives composition of the sample, which was determined by the standard analysis (Vogel 1951). The main undesirable impurities in the carbonate rocks are silica, $\mathrm{K}_{2} \mathrm{O}, \mathrm{Na}_{2} \mathrm{O}, \mathrm{Cl}^{-}$and alumina. These impurities combine with calcium oxide at elevated temperatures to form a slag, which reduce the pore volume and the amount of available active lime (Chan et al 1970). Such impurities either occurred in the matrix or came from the material in the crevices and other strata excavated along with limestone. Samples were chosen from quarries in which these impurities were low.

\subsection{Differential thermal analysis}

The typical DTA curve of dolomite sample is presented in figure 1 . The thermal curves representing the carbonate mineral are characterized by endothermic peaks at various temperatures caused by the evolution of carbon dioxide (figure 1). DTA curve of dolomite shows two endotherms at $772.6^{\circ} \mathrm{C}$ and $834^{\circ} \mathrm{C}$. The first one begins at $687^{\circ} \mathrm{C}$, reaches a peak at $773^{\circ} \mathrm{C}$ and ends at $781^{\circ} \mathrm{C}$ and the second one begins at $781^{\circ} \mathrm{C}$, reaches a peak at $834^{\circ} \mathrm{C}$ and ends at $916^{\circ} \mathrm{C}$. The lower temperature peak represents the decomposition of the dolomite structure, releasing carbon dioxide from the carbonate ion associated with magnesium part of the structure accompanied by the formation of calcite and magnesium oxide. The higher temperature peak represents the decomposition of calcite with the evolution of carbon dioxide (McInosh et al 1990). Mc Cauley and Johnson (1999) observed the peak temperatures at $790^{\circ} \mathrm{C}$ and $845^{\circ} \mathrm{C}$ for +16 mesh dolomite samples. However, Li and Messing (1983) reported the corresponding peak temperatures for $\mathrm{CaCl}_{2}$ doped dolomite sample at $750^{\circ} \mathrm{C}$ and $830^{\circ} \mathrm{C}$. This result suggests that the presence of salt $\left(\mathrm{Cl}^{-}\right)$enhances the decomposition of dolomite in the present study. The decomposition process is initiated at lower temperatures than observed for the pure dolomite. The salts promote the formation of $\mathrm{MgO}$ and $\mathrm{CaCO}_{3}$ during the early stage of decomposition. The ratio of the peak area $(\sim 5 \cdot 2)$ and the high characteristic temperature $\left(773^{\circ} \mathrm{C}\right)$ indicates that the dolomite is in well-ordered crystalline structure (Garn 1965), which is also confirmed through X-ray diffraction analysis. According to Barcina et al (1997), smaller size of magnesium with respect to calcium facilitates the magnesium mobility and thus the formation of carbon dioxide associated to magnesium oxide is kinetically favoured against the formation of $\mathrm{CO}_{2}$ associated to calcium oxide. The first endothermic peak of dolomite, however, caused by the reaction of more complicated mechanism, has inverted symmetry/shape index of 1.45 (Garn 1965). After calcinations, the resultant oxides have lower molar volumes, larger surface areas, and greater porosities than the carbonates. The calcination of a carbonate entails the formation of an oxide having a pseudo-lattice of the carbonate and subsequent recrystallization to the normal cubic lattice of the oxide. If the temperature is high enough, sintering of oxide takes place (Glasson 1958). The results indicate that the effect of $\mathrm{Fe}_{2} \mathrm{O}_{3}$ and $\mathrm{Al}_{2} \mathrm{O}_{3}$ on peak temperature is maximum when these oxides are present in low concentrations.

\subsection{Thermogravimetric analysis}

The typical TG curve of dolomite sample is presented in figure 1 . The observed weight loss was $1.33 \%$ below

Table 1. Results of the chemical analysis of samples (\%).

\begin{tabular}{lccccccccc}
\hline Sample code & $\mathrm{CaO}$ & $\mathrm{MgO}$ & $\mathrm{SiO}_{2}$ & $\mathrm{Fe}_{2} \mathrm{O}_{3}$ & $\mathrm{Al}_{2} \mathrm{O}_{3}$ & $\mathrm{~K}_{2} \mathrm{O}$ & $\mathrm{Na}_{2} \mathrm{O}$ & $\mathrm{Cl}^{-}$ & $\mathrm{LOI}$ \\
\hline$D_{01}$ & 30.24 & 21.33 & 0.18 & 0.63 & 0.25 & 0.03 & 0.23 & 0.19 & 46.04 \\
\hline
\end{tabular}


Table 2. Kinetic parameters for the thermal decomposition of dolomite in $\mathrm{N}_{2}$ atmosphere for different calculation methods.

\begin{tabular}{|c|c|c|c|c|c|c|c|c|c|c|c|}
\hline \multirow[b]{2}{*}{$\begin{array}{l}\text { Sample } \\
\text { code }\end{array}$} & \multicolumn{3}{|c|}{ Freeman-Carroll } & \multicolumn{3}{|c|}{ Coats-Redfern } & \multirow[b]{2}{*}{$n$} & \multirow[b]{2}{*}{$r$} & \multicolumn{3}{|c|}{ Horowitz-Metzger } \\
\hline & $\begin{array}{c}E \\
\left(\mathrm{~kJ} \mathrm{~mol}^{-1}\right)\end{array}$ & $\begin{array}{c}\log A \\
\left(\mathrm{~s}^{-1}\right)\end{array}$ & $\begin{array}{c}\mathrm{S} \\
\left(\mathrm{JK} \mathrm{mol}^{-1}\right)\end{array}$ & $\begin{array}{c}E \\
\left(\mathrm{~kJ} \mathrm{~mol}^{-1}\right)\end{array}$ & $\underset{\left(\mathrm{s}^{-1}\right)}{\log A}$ & $\begin{array}{c}S \\
\left(\mathrm{JK} \mathrm{mol}^{-1}\right)\end{array}$ & & & $\begin{array}{c}E \\
\left(\mathrm{~kJ} \mathrm{~mol}^{-1}\right)\end{array}$ & $\begin{array}{c}\log A \\
\left(\mathrm{~s}^{-1}\right)\end{array}$ & $\begin{array}{c}S \\
\left(\mathrm{JK} \mathrm{mol}^{-1}\right)\end{array}$ \\
\hline$D_{01}$ & $113 \cdot 56$ & $3 \cdot 246$ & $-133 \cdot 586$ & $123 \cdot 684$ & $3 \cdot 743$ & $-183 \cdot 851$ & $0 \cdot 15$ & 0.991 & 147.58 & $4 \cdot 346$ & $-172 \cdot 55$ \\
\hline
\end{tabular}

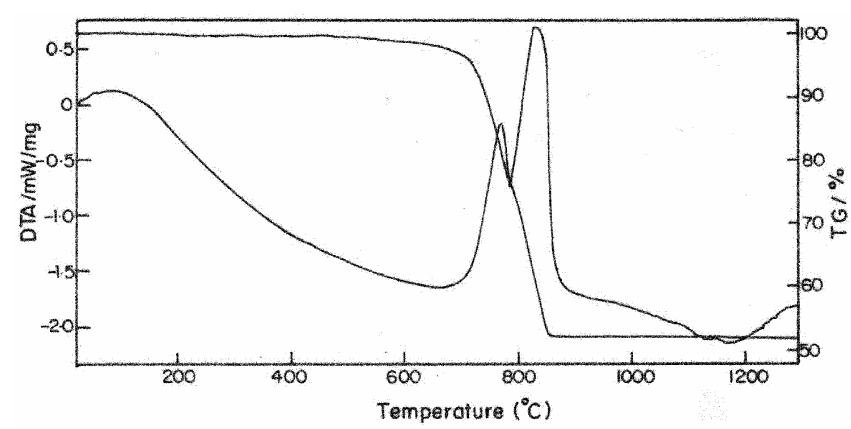

Figure 1. TG-DTA curves of dolomite.

$600^{\circ} \mathrm{C}$ and between $600^{\circ} \mathrm{C}$ and $850^{\circ} \mathrm{C}$, it was $46 \cdot 6 \%$. The weight loss detected in the temperature range $100-120^{\circ} \mathrm{C}$, was followed by a weight loss attributed to the decomposition of carbonates. The weight loss in this temperature range can be attributed to the chemically bound water. The kinetics of decomposition processes were analysed by means of the three popular methods (Freeman and Carroll 1958; Coats and Redfern 1964; Horowitz and Metzger 1963). Measured activation energies are given in table 2 and are in agreement with that reported by Criado and Ortega (1991) for pure dolomite sample. The measured activation energy indicates that $\mathrm{Cl}^{-}$do not activate the process by lowering the thermal requirements for decomposition. The slight variation in activation energy may be attributed to the difference in particle size and mineral origin in the samples. Lower the particle size, greater the fraction of molecules located on the surface with regard to the bulk. The wide dispersion of the available data is in relation to the influence of physical processes, viz. inter- and intra-particle diffusion, heat transfer resistance, sintering etc. Garcia Calvo et al (1990) studied the influence of macro-kinetic parameters on the value of the activation energy over a wide range of experimental conditions and concluded that the influence of macrokinetic parameter is low within this range. The calculated activation energy, $E$, increases with increasing concentration of the decomposition product $\left(\mathrm{CO}_{2}\right)$, which is similar to the observation of Ersoy-Merichoyu et al (1993). This change is attributed to the reversible nature of the decomposition reaction. The increase in $E$ is balanced by a corresponding increase in $A$ which is due to the compensation behaviour. If higher activation energies are obtained, the pre-exponential factors $(A)$ are higher too. The

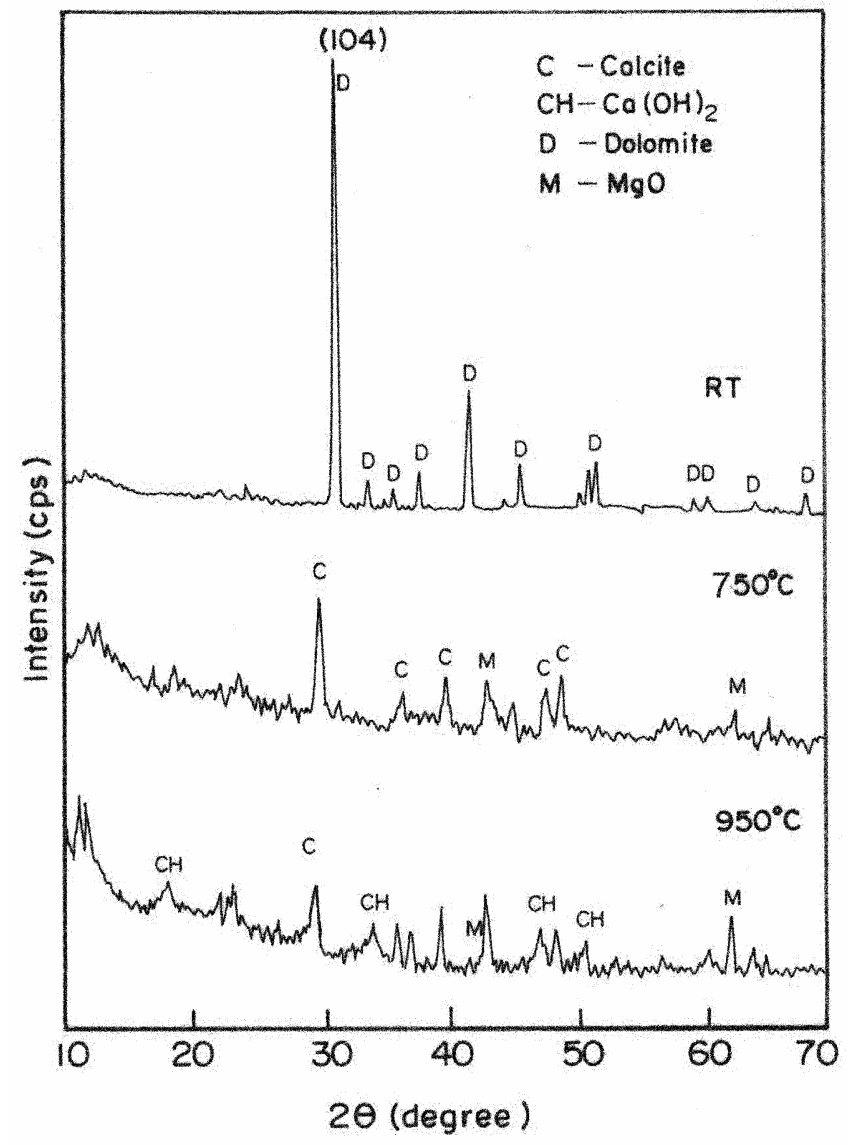

Figure 2. XRD pattern of dolomite at different temperatures.

observed kinetic parameters were found to be strongly affected by small amounts of impurities; however, the kinetic model is not affected. Comparison of the values of $E$ and $A$ in the present study with those values of pure calcite reported by Garcia Calvo et al (1990) indicates that the presence of impurities is a cause of variation of kinetic parameters obtained. The impurities could function as catalysts owing to their influence in the crystalline structure.

\subsection{X-ray diffraction analysis}

Figure 2 depicts the powder X-ray diffraction pattern of natural dolomite sample at different temperatures. The room temperature XRD pattern of the sample displays 
Table 3. Indexed powder XRD pattern for natural dolomite.

\begin{tabular}{|c|c|c|c|c|c|c|c|c|c|}
\hline S1. no. & $h$ & $k$ & $l$ & $d(\AA)$ obs & $d(\AA) \mathrm{cal}$ & Diff. $D(\AA)$ & $\begin{array}{c}2 \theta(\text { degree }) \\
\text { obs }\end{array}$ & $\begin{array}{c}2 \theta(\text { degree }) \\
\text { cal }\end{array}$ & $\begin{array}{l}\text { Diff. } 2 \theta \\
\text { (degree) }\end{array}$ \\
\hline 1 & 0 & 1 & 2 & 3.6917 & 3.6906 & 0.0011 & 24.087 & 24.094 & -0.007 \\
\hline 2 & 1 & 0 & 4 & $2 \cdot 8884$ & $2 \cdot 8887$ & -0.0003 & $30 \cdot 935$ & $30 \cdot 931$ & 0.004 \\
\hline 3 & 0 & 0 & 6 & $2 \cdot 6720$ & $2 \cdot 6724$ & -0.0004 & $33 \cdot 511$ & $33 \cdot 506$ & 0.005 \\
\hline 4 & 0 & 1 & 5 & $2 \cdot 5417$ & $2 \cdot 5408$ & 0.0009 & $35 \cdot 283$ & $35 \cdot 296$ & $-0 \cdot 013$ \\
\hline 5 & 1 & 1 & 0 & 2.4100 & 2.4104 & -0.0004 & 37.281 & 37.275 & 0.006 \\
\hline 6 & 1 & 1 & 3 & $2 \cdot 1974$ & $2 \cdot 1975$ & -0.0001 & 41.042 & 41.040 & 0.002 \\
\hline 7 & 0 & 2 & 1 & $2 \cdot 0209$ & $2 \cdot 0214$ & -0.0005 & $44 \cdot 812$ & $44 \cdot 801$ & $0 \cdot 011$ \\
\hline 8 & 0 & 2 & 4 & 1.8519 & 1.8522 & -0.0003 & $49 \cdot 158$ & $49 \cdot 150$ & 0.008 \\
\hline 9 & 0 & 1 & 8 & 1.8095 & 1.8098 & -0.0003 & $50 \cdot 390$ & $50 \cdot 380$ & $0 \cdot 010$ \\
\hline 10 & 1 & 1 & 6 & 1.7920 & 1.7919 & $0 \cdot 0001$ & $50 \cdot 918$ & $50 \cdot 919$ & -0.001 \\
\hline 11 & 2 & 1 & 1 & 1.5722 & 1.5726 & -0.0004 & 58.676 & 58.659 & 0.017 \\
\hline 12 & 1 & 2 & 2 & $1 \cdot 5493$ & $1 \cdot 5495$ & -0.0002 & 59.628 & $59 \cdot 620$ & $0 \cdot 008$ \\
\hline 13 & 2 & 1 & 4 & 1.4698 & 1.4698 & 0.0000 & $63 \cdot 214$ & $63 \cdot 214$ & $0 \cdot 000$ \\
\hline 14 & 0 & 3 & 0 & $1 \cdot 3933$ & $1 \cdot 3934$ & $-0 \cdot 00008$ & $67 \cdot 126$ & $67 \cdot 121$ & $0 \cdot 005$ \\
\hline
\end{tabular}

Table 4. Unit cell parameters of natural dolomite at different temperatures.

\begin{tabular}{lcccl}
\hline Temperature $\left({ }^{\circ} \mathrm{C}\right)$ & $a(\AA)$ & $c(\AA)$ & $c / a(\AA)$ & Volume $(\AA)^{3}$ \\
\hline$R T$ & $4 \cdot 8247$ & $15 \cdot 9680$ & $3 \cdot 3135$ & $322 \cdot 28$ \\
650 & 4.9680 & $17 \cdot 1008$ & 3.4422 & $365 \cdot 5$ \\
750 & $5 \cdot 0103$ & $17 \cdot 0146$ & 3.3959 & $369 \cdot 9$ \\
850 & $5 \cdot 0466$ & $16 \cdot 9380$ & $3 \cdot 3563$ & $373 \cdot 6$ \\
950 & $5 \cdot 0348$ & $16 \cdot 9558$ & 3.3671 & $372 \cdot 2$ \\
\hline
\end{tabular}

Table 5. FWHM of principal reflections of dolomite for different heat treatments.

\begin{tabular}{lll}
\hline & \multicolumn{2}{c}{ Dolomite } \\
\cline { 2 - 3 } Temperature $\left({ }^{\circ} \mathrm{C}\right)$ & $(104)$ & $(202)$ \\
\hline 650 & $0 \cdot 16$ & $0 \cdot 24$ \\
750 & $0 \cdot 16$ & $0 \cdot 24$ \\
850 & $0 \cdot 16$ & $0 \cdot 12$ \\
950 & $0 \cdot 16$ & $0 \cdot 16$ \\
\hline
\end{tabular}

Table 6. Observed X-ray data for the heat treated dolomite sample $\left(750^{\circ} \mathrm{C}\right)$ and reported data for calcite.

\begin{tabular}{|c|c|c|c|c|}
\hline \multirow[b]{2}{*}{$(h k l)$} & \multicolumn{3}{|c|}{$d(\AA)$ for calcite } & \multirow[b]{2}{*}{ Intensity } \\
\hline & Observed & Reported & $\begin{array}{c}\text { JCPDS } \\
\text { Card 5-586 }\end{array}$ & \\
\hline$\left(\begin{array}{lll}0 & 1 & 2\end{array}\right)$ & $3 \cdot 8409$ & $3 \cdot 8520$ & $3 \cdot 80$ & 12 \\
\hline$\left(\begin{array}{lll}1 & 0 & 4\end{array}\right)$ & 3.0334 & $3 \cdot 0300$ & 3.035 & 100 \\
\hline$\left(\begin{array}{lll}0 & 0 & 6\end{array}\right)$ & $2 \cdot 8889$ & $2 \cdot 8340$ & $2 \cdot 845$ & 3 \\
\hline$\left(\begin{array}{lll}1 & 1 & 0\end{array}\right)$ & 2.4993 & 2.4950 & 2.495 & 14 \\
\hline$\left(\begin{array}{lll}1 & 1 & 3\end{array}\right)$ & $2 \cdot 2877$ & $2 \cdot 2840$ & $2 \cdot 285$ & 18 \\
\hline$\left(\begin{array}{lll}2 & 0 & 2\end{array}\right)$ & $2 \cdot 1084$ & $2 \cdot 0940$ & 2.095 & 18 \\
\hline$\left(\begin{array}{lll}0 & 2 & 4\end{array}\right)$ & 1.9179 & 1.9260 & - & - \\
\hline$\left(\begin{array}{lll}1 & 1 & 6\end{array}\right)$ & 1.8837 & 1.8750 & 1.875 & 17 \\
\hline$\left(\begin{array}{lll}2 & 1 & 5\end{array}\right)$ & 1.4968 & 1.4730 & 1.473 & 2 \\
\hline
\end{tabular}

ASTM card no. (24-274).
Table 7. Vibrational frequency assignments (FT-IR).

\begin{tabular}{lccccc}
\hline $\begin{array}{l}v_{1} \\
\left(\mathrm{~cm}^{-1}\right)\end{array}$ & $\begin{array}{c}v_{2} \\
\left(\mathrm{~cm}^{-1}\right)\end{array}$ & $\begin{array}{c}v_{3} \\
\left(\mathrm{~cm}^{-1}\right)\end{array}$ & $\begin{array}{c}v_{4} \\
\left(\mathrm{~cm}^{-1}\right)\end{array}$ & $\begin{array}{c}v_{1}+v_{4} \\
\left(\mathrm{~cm}^{-1}\right)\end{array}$ & $\begin{array}{c}2 v_{2}+v_{4} \\
\left(\mathrm{~cm}^{-1}\right)\end{array}$ \\
\hline- & 881 & 1446 & 726 & 1881 & 2525 \\
\hline
\end{tabular}

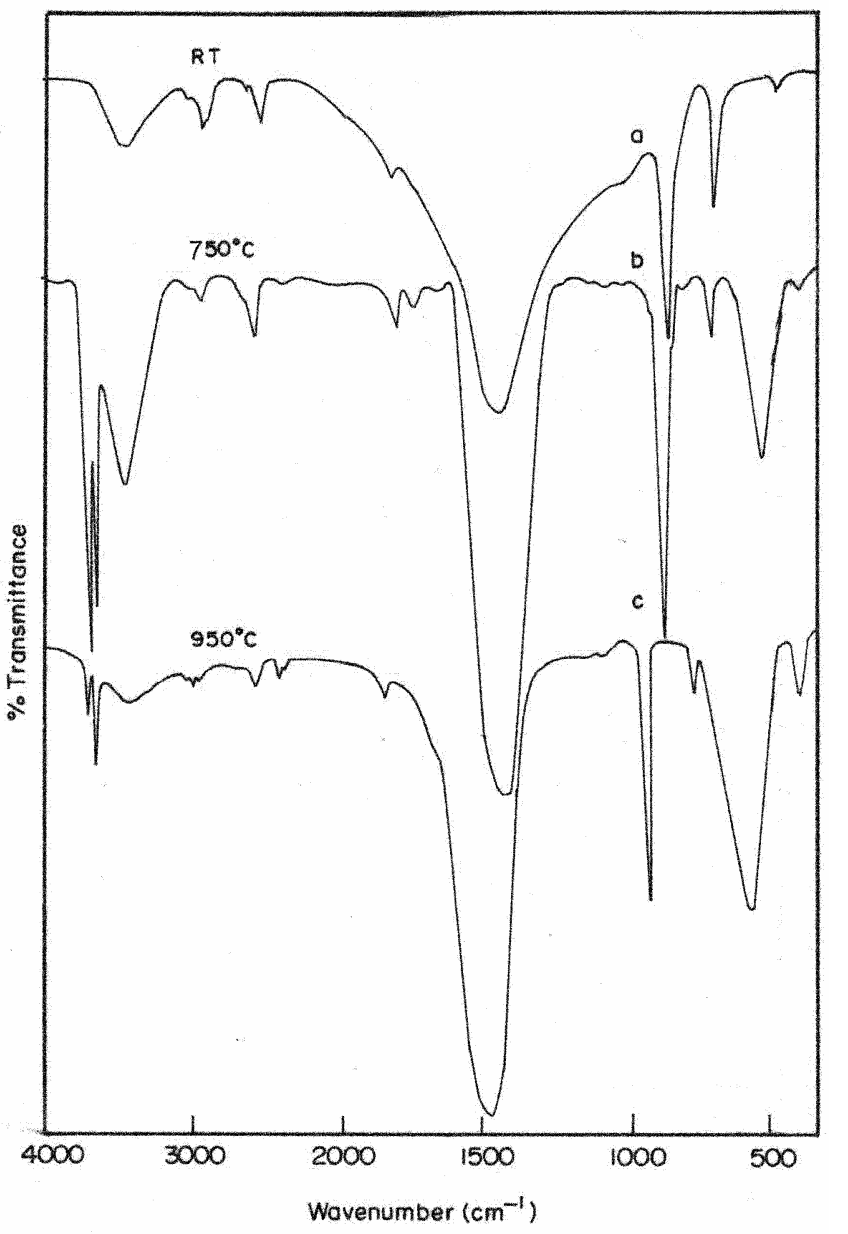

Figure 3. FTIR spectra of dolomite at different temperatures. 


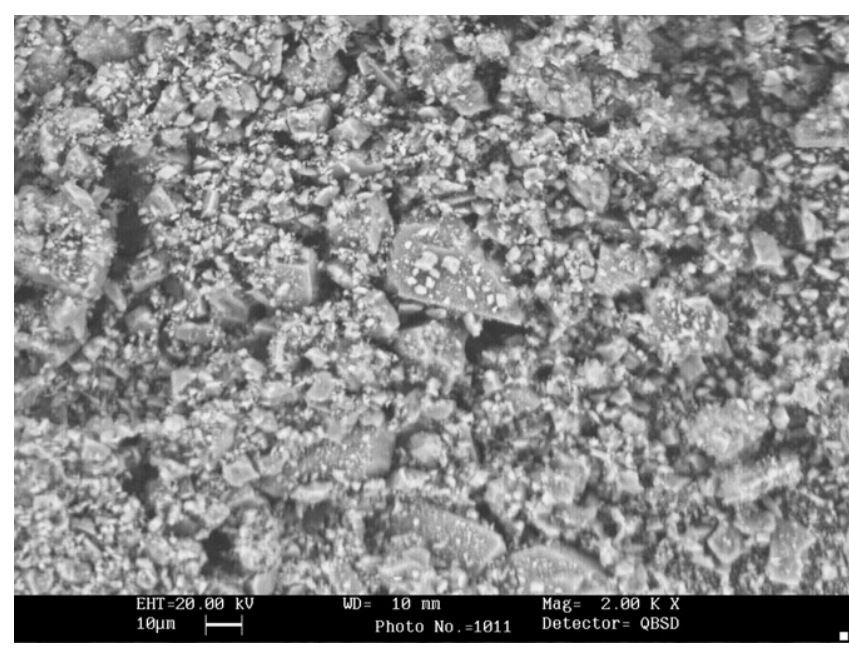

Figure 4. SEM photograph of dolomite at room temperature.

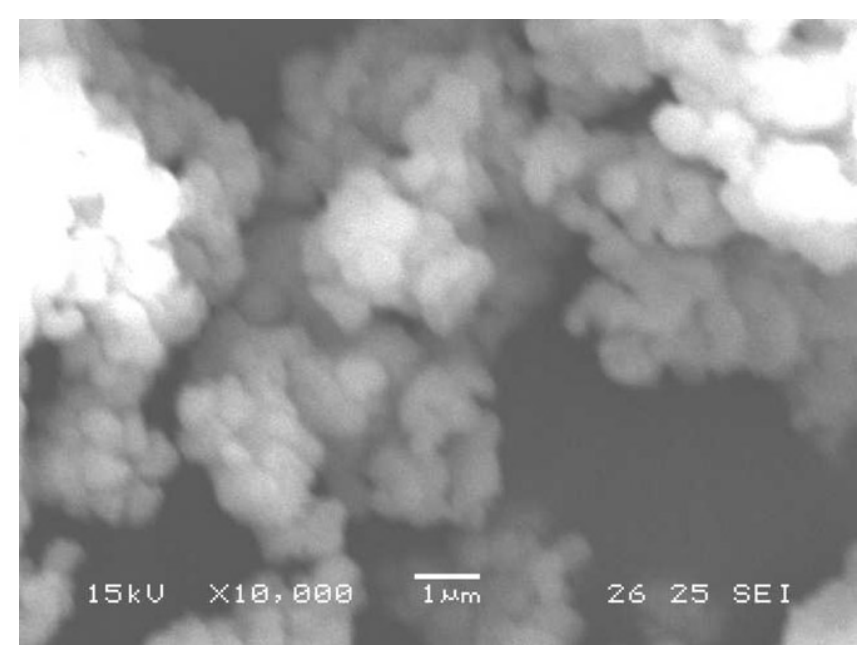

Figure 5. SEM photograph of dolomite at $950^{\circ} \mathrm{C}$.

sharp diffractions that can be attributed to dolomite (JCPDS Files card 11-78; 1999). Table 3 gives various Bragg reflections that are indexed using JCPDS Files card 11-78 and the calculated unit cell dimensions of natural dolomite at different temperatures are compiled in table 4. In table 5, FWHM of (104) and (202) reflections of dolomite are compared for different heat treatments. It can be noticed that the general pattern remains the same and in addition, there is no change in the FWHM of the (104) reflection. However, the (202) reflection shows slight decrease in the FWHM value. The original reflection disappeared completely and new lines are developed at the asymmetric positions of (104) and (202) reflections. In table 6, the $d$ spacing of the reflections observed for $750^{\circ} \mathrm{C}$ heat treatment is compared with those reported in the literature for calcite indicating that the crystal structure of dolomite has been transformed completely to calcite structure during heat treatment.

\subsection{FTIR spectral analysis}

The typical transmittance FTIR spectra of the dolomite mineral are shown in figure 3 . In the room temperature FTIR spectra of the samples, the out-of-plane bending $\left(v_{2}\right)$, the asymmetric stretching $\left(v_{3}\right)$, and the in-plane bending $\left(v_{4}\right)$ modes of the carbonate group are found to be active. Besides the internal modes, the $v_{2}+v_{4}$ combination mode has also been observed (Adler and Kerr 1963; White 1974; Legodi et al 2001) and the observed bands are compiled in table 7 . Additionally peaks due to silicates $\left(1088 \mathrm{~cm}^{-1}\right)$ and $\mathrm{H}$-bonded water $\left(\right.$ at $\left.3400 \mathrm{~cm}^{-1}\right)$ are visible (Keeling 1963). In addition, the weak band due to quartz $\left(465 \mathrm{~cm}^{-1}\right)$ is also visible. The characteristic dolomite bands are shifted to 713,876 and $420 \mathrm{~cm}^{-1}$ in the FTIR spectra of $750^{\circ} \mathrm{C}$ heat-treated dolomite sample (figure 3). This clearly indicates the structural transformation of dolomite to calcite. At this stage, a strong and broad band at $540 \mathrm{~cm}^{-1}$ due to magnesium oxide is also visible. At $950^{\circ} \mathrm{C}$, the $1420 \mathrm{~cm}^{-1}$ band shifted to $1413 \mathrm{~cm}^{-1}$ and the intensity of the band, $713 \mathrm{~cm}^{-1}$, very much decreased. SEM microphotographs of the heat-treated and untreated samples are shown in figures 4 and 5. SEM microphotograph of the untreated samples shows distinct grains, however, the heat-treated $\left(950^{\circ} \mathrm{C}\right)$ samples exhibit clusters of grains confirming the thermal decomposition.

\section{Conclusions}

DTA curve of dolomite shows two peaks at $777 \cdot 8^{\circ} \mathrm{C}$ and $834^{\circ} \mathrm{C}$. The two-stage decomposition reaction is confirmed by FTIR and XRD analysis. At $750^{\circ} \mathrm{C}$, the dolomite structure is changed into calcite, which is confirmed by the presence of calcite characteristic peaks in the FTIR spectra at 713,875 and $1420 \mathrm{~cm}^{-1}$. The presence of characteristic reflections at 3.0334 and $2.4993 \AA$ for calcite and $\mathrm{MgO}$, respectively also confirm the first stage decomposition of dolomite. At $950^{\circ} \mathrm{C}$, the thermal decomposition reaction is completed which is confirmed by FTIR and XRD analysis. The large fluctuation in the observed activation energies is due to the presence of impurities in the samples. The impurities could function as catalysts owing to their influence in the crystalline structure. The results show that the clay with which they are heated which is reflected by the differences in the activation energy, affects dolomite decomposition. These results could be important in site consideration of the dolomite sample.

\section{References}

Adler H H and Kerr P F 1963 Am. Mineral. 48839

Barcina L M, Espina A, Suarez M, Garcia J R and Rodriguez J 1997 Thermochim. Acta 290181

Borgwardt R H 1985 AIchE 31103

Chan R K, Murthi K S and Harrison D 1970 Can. J. Chem. 48 2972 
Coats A W and Redfern J P 1964 Nature (London) 20168

Criado J M and Ortega A 1991 J. Thermal Anal. \& Calorimetry 372369

Criado J M and Ortega A 1992 Thermochim Acta 195163

Ersoy-Merichoyu A, Kuchkbayrak S and Durus B $1993 \mathrm{~J}$. Thermal Anal. 39707

Freeman E S and Carroll B 1958 J. Phys. Chem. 62394

Garcia Calvo E, Arranz M A and Leton P 1990 Thermochim. Acta 1707

Garn D D 1965 Thermoanalytical methods of investigation (New York: Academic Press)

Glasson D R 1958 J. Appl. Chem. 8793

Horowitz H H and Metzger G 1963 Anal. Chem. 351464

Iwafuchi K, Watanabe C and Otsuka R 1983 Thermochim. Acta 66105

JCPDS Files card 5-586 and 11-78 1999

Keeling P S 1963 Trans. Br. Ceram. Soc. (GB) 62549

Kunel D, Modi and Jadhav K M 1997 Indian J. Pure \& Appl. Phys. 25594

Legodi M A, deWaal D and Potgieter J H 2001 Appl. Spectrosc. 55361
Li Mao Qiang and Messing G L 1984 Thermochim Acta 789

Mc Cauley R A and Johnson L A 1991 Thermochim. Acta 185 27

McInosh L M, Sharp J H and Willburn F W 1990 Thermochim. Acta 165281

Mulokozi A M and Lugwisha E 1992 Thermochim. Acta 194375

Powell E K and Searcy A W 1980 Metall. Trans. B11 427

Romero Salvador A, Garcia Calvo E and Beneitz Aparico M 1989 Thermochim. Acta 143339

Rubiera F, Fuertes A B, Pis J J, Artos V and Marban G 1991 Thermochim. Acta 179125

Shoval S, Gaft M, Beck P and Krish V 1993 J. Thermal Anal. 40263

Vogel A I 1951 Quantitative inorganic analysis (London: Longmans) p. 582

Warne S S J, Morgan D J and Milondowshi A E 1981 Thermochim. Acta $\mathbf{5 1} 105$

White W B 1974 Min. Soc. Monogr. 4227

Xiao K, Sichen D U, Sohn H Y and Seetharaman S 1997 Metall. and Mater. Trans. B28 1157

Yariv Shmuel 1989 Thermochim. Acta 148421 